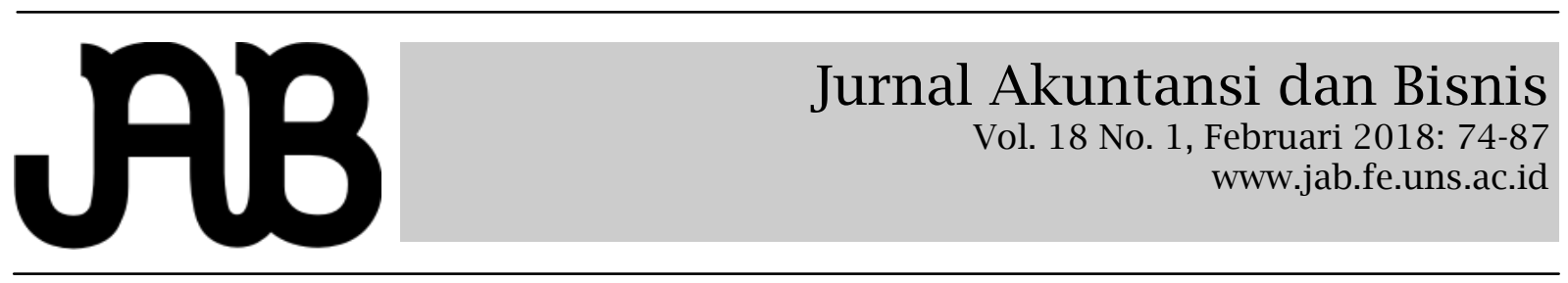

\title{
KARAKTERISTIK PERUSAHAAN, ISO 14001, DAN PENGUNGKAPAN LINGKUNGAN: STUDI KOMPARATIF DI INDONESIA DAN THAILAND
}

\author{
SEPTALIA RAHMAWATI (septaliarahma@gmail.com) \\ CHRISTIYANINGSIH BUDIWATI (christiyaningsih.budiwati@gmail.com)
}

Program Studi Akuntansi, Fakultas Ekonomi dan Bisnis, Universitas Sebelas Maret, Indonesia

\begin{abstract}
A B S T R A C T
This study aims to examine the difference of environmental disclosures between the Indonesian and Thailand mining companies, also to examine the effects of the characteristics of the companies and ISO 14001 towards environmental disclosures. This study uses firm size, firm age and profitability for the companies' characteristics. The companies' environmental disclosures were measured with the newest GRI G4 index. This study also uses the mining companies' annual reports in 2014-2016 that are listed in the Indonesia Stock Exchange (IDX) and the Stock Exchange of Thailand (SET) as the secondary data population. Furthermore, the number of samples in this research are 117 samples from 22 mining companies in Indonesia and 17 mining companies in Thailand that were generated by using purposive sampling method. The first objective has been examined by using Independent Samples $T$ Test and it obtained a result that there are differences of environmental disclosure between Indonesia and Thailand mining companies. Meanwhile, the second and third objectives of this research were examined by using multiple regression analysis. The result shows that there are significant positive effects given by the firm size, the firm age and ISO 14001. Moreover, the profitability gives no significant positive effect towards environmental disclosures.

Keywords: Company Characteristic, ISO 14001, Environmental Disclosure.

Penelitian ini bertujuan untuk meneliti perbedaan pengungkapan lingkungan perusahaan pertambangan di negara Indonesia dan Thailand, serta meneliti karakteristik perusahaan dan ISO 14001 pengaruhnya terhadap pengungkapan lingkungan. Studi ini menggunakan ukuran perusahaan, umur perusahaan, dan profitabilitas untuk karakteristik perusahaan. Pengungkapan lingkungan perusahaan diukur dengan indeks GRI G4 terbaru. Studi ini menggunakan populasi data sekunder dari laporan keuangan perusahaan-perusahaan pertambangan yang terdaftar pada Bursa Efek Indonesia (BEI) dan Bursa Efek Thailand (SET) tahun 2014 2016. Studi ini menggunakan sampel penelitian purposive sampling yaitu sebanyak 117 sampel dari 22 perusahaan pertambangan di Indonesia dan 17 perusahaan pertambangan di Thailand. Uji beda digunakan untuk tujuan penelitian pertama dan hasilnya terdapat perbedaan pengungkapan lingkungan di Indonesia dan Thailand. Uji regresi linier berganda digunakan untuk tujuan penelitian kedua dan ketiga. Hasil menunjukkan adanya pengaruh positif signifikan yaitu ukuran perusahaan, umur perusahaan, dan ISO 14001 terhadap pengungkapan lingkungan serta tidak adanya pengaruh antara profitabilitas terhadap pengungkapan lingkungan perusahaan.

Kata kunci: Karakteristik Perusahaan, ISO 14001, Pengungkapan Lingkungan.
\end{abstract}

\section{PENDAHULUAN}

Pengaruh aktivitas perusahaan terhadap lingkungan mendapatkan perhatian besar dari masyarakat akhir-akhir ini. Pertumbuhan ekonomi yang cepat membuat konsumsi sumber daya dan masalah polusi lingkungan bertambah serius. Banyak perusahaan biasanya melalaikan manfaat tanggungjawab sosial dan lingkungan serta hanya memaksimalkan keuntungan (Zhongfu, Jianhui \& Pinglin, 2011). Corporate social and environmental disclosure merupakan sebuah dialog diantara perusahaan dan stakeholders perusahaan yaitu mereka yang tertarik pada aktivitas sosial dan lingkungan perusahaan sehingga menunjukkan pemenuhan tanggungjawab sosial dan lingkungan perusahaan kepada stakeholders (Lu \& Abeysekera, 2014). 
Elkington (1998) mengemukakan triple bottom line untuk merepresentasikan tiga komponen pembangunan berkelanjutan yaitu sosial, lingkungan, dan ekonomi atau people planet profit (3P). Corporate Social and Responsibility (CSR) perusahaan bisa menjamin keberlanjutan perusahaan dengan tidak merusak keberlanjutan lingkungan serta masyarakat sehingga tidak hanya profit oriented tetapi harus mengutamakan triple bottom line (Budiarti \& Raharjo, 2017). Permintaan perusahaan untuk melakukan pengungkapan lingkungan sangat tinggi (Nor, Bahari, Adnan, Kamal \& Ali, 2016). Citra (image) dan kepercayaan terhadap perusahaan akan meningkat (Hanny \& Nurfrianto, 2016). Investor akan menilai perusahaan tidak mampu mempertahankan keberlanjutan usahanya sehingga tidak tertarik menginvestasikan saham pada perusahaan yang tidak melakukan pengungkapan (Yuliana, Purnomosidhi \& Sukoharsono, 2008). Beberapa alasan pentingnya tanggungjawab sosial dan lingkungan yaitu membangun kedekatan hubungan dengan stakeholders dan pelaku bisnis serta meningkatkan transparansi (Gray, 1992) serta diperolehnya manfaat keuntungan kompetitif (Hoq, Saleh \& Zubayer, 2010).

Intergovernmental Panel on Climate Change (IPCC) menyatakan perkembangan ekonomi di Asia dihadapkan oleh masalah lingkungan yang serius. Badan Kesehatan Dunia (WHO) mengeluarkan laporan bahwa polusi udara di lebih dari dua pertiga kota Asia Tenggara meningkat sebanyak lima persen (Syarifah, 2016) dan negara berkembang di kawasan ini rentan tercemar udaranya umumnya karena banyaknya mobil, motor, terutama kendaraan berbahan bakar diesel, pengelolaan limbah, hingga pembangkit listrik batubara (Maharani, 2016). Data indikator energi dan emisi karbondioksida menunjukkan Indonesia dan Thailand termasuk sepuluh besar kawasan dengan peningkatan karbon tertinggi (Howes \& Wyrwoll, 2012).

Penurunan ekosistem lingkungan berupa produktivitas perikanan laut diakibatkan naiknya kekeruhan air laut karena aktivitas tambang pasir perusahaan di Kabupaten Takalar, Sulawesi Selatan (Walhi, 2017). Aktivitas operasi PT Indominco Mandiri yaitu anak perusahaan PT Indo Tambangraya Megah Tbk (PT ITM) mengakibatkan perubahan warna air sehingga menurunnya kualitas air sungai diikuti dengan matinya ikan-ikan yang merupakan sumber penghasilan masyarakat di hulu Sungai Santan (Kosasih, 2017). Kasus di Thailand yaitu adanya masalah tambang emas di Phichit dan Loei kawasan industri Tan Ta Farm di Rayong dan konflik lingkungan yang terkait dengan pengelolaan limbah. Ecological Alert and Recovery Thailand (EARTH) merilis sebuah laporan tentang polusi di Thailand pada tahun 2015 dan 2016 yaitu stasiun pemantauan polusi yang mendeteksi senyawa organik volatil dalam jumlah tinggi di luar tingkat aman (Rujivanarom, 2017). PTT Exploration and Production Public (PTTEP) Company Limited di wilayah operasional Montara meledak mengakibatkan minyak tumpah dan mengalir ke Laut Timor yang berada di antara perairan Indonesia dan Australia menimbulkan kerugian lingkungan kepada petani rumput laut dan nelayan (Lavinda, 2017).

Wuttichindanon (2017) di Thailand meneliti government ownership, firm size, age, profitability, dan leverage menunjukkan firm size berpengaruh positif signifikan sedangkan age dan profitability tidak memiliki pengaruh terhadap corporate social responsibility disclosure. $\mathrm{Lu}$ dan Abeysekera (2014) di China meneliti firm size, profitability, industry classification, powerful stakeholders, shareholders, dan creditors menunjukkan firm size dan profitability berpengaruh positif signifikan terhadap social and environmental disclosure. Penelitian Yusoff dan Lehman (2006) menunjukkan bahwa ISO 14001 menjadi motivasi perusahaan di Australia dan Malaysia untuk melakukan corporate environmental disclosure. Dianawati (2017) meneliti pengalaman internasional, kedekatan konsumen, dan sertifikasi lingkungan menunjukkan sertifikasi lingkungan diantaranya ISO 14001 tidak memiliki pengaruh terhadap pengungkapan corporate social responsibility.

Terdapat beberapa hasil yang bertentangan pada penelitian sebelumnya maka mendorong peneliti meneliti kembali bagaimana pengaruh karakteristik perusahaan dan sertifikasi ISO 14001 terhadap pengungkapan lingkungan. Penelitian ini melakukan perbandingan luas pengungkapan lingkungan di Indonesia dan Thailand karena kedua negara tersebut termasuk negara dengan peningkatan karbon tertinggi dan memiliki jumlah perusahaan pertambangan terbanyak dibandingkan negara Asia Tenggara lainnya sehingga dapat mewakili populasi. Rumusan masalah dalam penelitian ini yaitu peneliti ingin mengetahui perbedaan pengungkapan lingkungan di negara Indonesia dan Thailand, pengaruh karakteristik perusahaan meliputi ukuran perusahaan, umur, dan profitabil- 
itas terhadap pengungkapan lingkungan perusahaan. Selain itu, peneliti ingin mengetahui pengaruh ISO 14001 terhadap pengungkapan lingkungan perusahaan pertambangan yang terdaftar pada Bursa Efek Indonesia (BEI) serta Bursa Efek Thailand (SET) tahun 2014-2016 dan diharapkan memberikan kontribusi pada praktek pengungkapan lingkungan perusahaan serta merepresentasikan keadaan sekarang. Bagian akhir pendahuluan artikel ini akan menguraikan literatur dan pengembangan hipotesis diperkuat dengan hasil penelitian sebelumnya. Metode penelitian akan menjelaskan teknik pengumpulan dan analisis data. Hasil dan pembahasan akan dijabarkan untuk menjelaskan aspek penelitian serta kesimpulan, saran, keterbatasan, dan implikasi menjadi penutup pada penelitian ini.

\section{T I N J A U A P US T A K A D A N PENGEMBANGAN HIPOTESIS \\ Teori Stakeholder}

Teori stakeholder merupakan salah satu isu strategis berkaitan dengan bagaimana perusahaan mengelola hubungan dengan para pemangku kepentingan (Bani-Khalid \& Kouhy, 2017). Orientasi perusahaan bergeser dari yang diorientasikan kepada shareholder (shareholder orientation) yang bertitik tolak pada ukuran kinerja ekonomi semata ke arah kesinambungan lingkungan dan masyarakat dengan memperhitungkan dampak lingkungan dan sosial (shareholder orientation) (Hadi, 2011). Ulhøi dan Madsen (2013) membagi stakeholder menjadi stakeholder primer (pemilik, karyawan dan rekan kerja) dan stakeholder sekunder (kelompok kepentingan lingkungan dan organisasi non pemerintah). Menurut teori stakeholder, perusahaan merupakan entitas yang harus memberikan manfaat kepada stakeholder-nya bukan saja beroperasi untuk kepentingan perusahaan itu sendiri (Rosiana, Juliarsa \& Sari, 2013).

\section{Pengungkapan Lingkungan Hidup}

Laporan keuangan maupun komunikasi tambahan (suplementary communication) terdiri atas informasi meliputi informasi kejadian setelah tanggal laporan, catatan kaki, analisis manajemen atas operasi perusahaan dimasa mendatang, perkiraan mendatang, perkiraan keuangan dan operasi, serta informasi lainnya merupakan pengungkapan dalam interprestasi luas (Zuhroh \& Sukmawati, 2013). Financial Accounting Standards Board (FASB) concept statement nomor 1 menyatakan perusahaan dalam laporan keuangan sebaiknya menyajikan informasi yang penting dan media pelaporan lain dapat menyajikan beberapa informasi lainnya. Informasi yang dibutuhkan pemegang saham mengenai pengungkapan lingkungan yang diaudit dapat menjamin kehandalan dan daya tahan pertanggungjawaban manajer pada dampak lingkungan dari keputusan yang dibuat (De Villiers \& Van Staden, 2010).

$$
\text { Tanggungjawab sosial dan }
$$

lingkungan berhubungan dengan sustainability report. Laporan keberlanjutan (sustainability report) menjelaskan tentang pengungkapan dampak terpenting organisasi terhadap lingkungan, masyarakat, dan ekonomi baik positif maupun negarif. Instrumen pengukuran pengungkapan lingkungan pada studi ini menggunakan indeks Global Reporting Initiative (GRI)-G4 merupakan standar pengukuran CSR diterbitkan Mei 2013 untuk membantu pelapor menyusun laporan keberlanjutan yang terdiri dari dampak berhubungan dengan input (energi dan air) dan output (emisi, efluen, dan limbah), keanekaragaman hayati, transportasi, dan produk dan jasa, serta berkaitan kepatuhan dan biaya lingkungan (GRI, 2013). Penelitian terdahulu belum ada yang melakukan perbandingan karakteristik perusahaan dan sertifikasi ISO 14001 terhadap luas pengungkapan lingkungan di Indonesia dan Thailand. Oleh karena itu penelitian ini akan menguji perbandingan pengungkapan lingkungan lintas negara tersebut.

\section{Regulasi Pengungkapan Lingkungan di Indonesia}

Pemerintah Indonesia merespon dengan mengeluarkan Undang-Undang Republik Indonesia Nomor 40 Tahun 2007 mengenai Perseroan Terbatas pasal 66 mengenai laporan tahunan harus berisi minimal laporan pelaksanaan tanggung jawab sosial dan lingkungan dan pasal 74 ayat 1 yaitu wajib melaksanakan tanggung jawab sosial dan lingkungan bagi perseroan yang menjalankan usahanya di bidang dan/atau berkaitan dengan sumber daya alam. Otoritas Jasa Keuangan (OJK) mengeluarkan Peraturan Otoritas Jasa Keuangan Nomor 51/POJK.03/2017 mengenai Penerapan Keuangan Berkelanjutan bagi Lembaga Jasa Keuangan, Emiten, dan Perusahaan Publik yaitu diperlukan sistem perekonomian nasional yang mengedepankan keselarasan antara aspek ekonomi, sosial, dan lingkungan hidup untuk mewujudkan 
pembangunan berkelanjutan yang mampu menjaga stabilitas ekonomi serta bersifat inklusif. Ikatan Akuntan Indonesia (IAI) dalam Pernyataan Standar Akuntansi Keuangan (PSAK) Nomor 1 Paragraf 9 tentang Penyajian Laporan Keuangan yaitu laporan tambahan pengungkapan tentang dampak lingkungan dapat disajikan perusahaan.

\section{Regulasi Pengungkapan Lingkungan di Thailand}

Perkembangan industri yang pesat dan kerusakan lingkungan terjadi karena transisi ekonomi dari pertanian ke ekonomi swasembada menjadi negara industri telah mendorong Bursa Efek Thailand (SET) di tahun 1999 memperkenalkan prinsip-prinsip baru tata kelola perusahaan. Prinsip tersebut secara sukarela mengungkapkan informasi isu-isu sosial dan lingkungan pada laporan tahunan di samping informasi keuangan untuk perusahaan-perusahaan yang terdaftar di SET (Suttipun \& Stanton, 2012). SET mengumumkan di tahun 2006 adanya perubahan mengenai prinsip-prinsip tata kelola perusahaan yang baik bagi perusahaan terdaftar. Dewan direksi harus menentapkan kebijakan yang jelas mengenai masalah pelaksanaan lingkungan dan sosial serta wajib melakukan pengungkapan lingkungan dan sosial. SET meminta perusahaan melakukan pengungkapan prinsip baru yaitu menetapkan, menerapkan dan mengungkapkan serta dari sukarela ke mematuhi persyaratan substantif atau menjelaskan mulai tahun 2007 (Lin, 2009). Pada tahun 2008 SET resmi mengumumkan kewajiban perusahaan terdaftar untuk melakukan pengungkapan lingkungan dan sosial dalam laporan tahunan.

\section{Ukuran Perusahaan}

Ukuran perusahaan dapat mengklasifikasikan skala besar kecilnya perusahaan dapat dilihat dari berbagai aspek, misalkan total nilai aktiva atau aset, kapitalisasi pasar, total penjualan, dan jumlah tenaga kerja. Semakin besar ukuran tersebut, semakin besar pula ukuran perusahaan (Akbar, 2015). Penelitian ini menggunakan proxy jumlah total aset perusahaan.

\section{Umur Perusahaan}

Santioso dan Chandra (2012) dalam penelitiannya menyatakan bahwa perusahaan tetap eksis dan mampu bersaing dapat dilihat pada umur perusahaannya.
Perusahaan dengan tingkat umur lebih tua lebih banyak memiliki informasi daripada perusahaan yang lebih muda (Paramitha \& Rohman, 2014).

\section{Profitabilitas}

Profitabilitas yaitu rasio untuk mengukur kemampuan perusahaan dalam mendapatkan keuntungan di tingkat penjualan, aset, dan ekuitas (Kamil \& Herusetya, 2012).

\section{ISO 14001}

ISO 14001 merupakan standar internasional yang menentukan persyaratan untuk pendekatan manajemen yang terstruktur untuk perlindungan lingkungan. ISO 14001 (Sistem Manajemen Lingkungan) adalah sistem manajemen perusahaan yang berguna memastikan proses dan produk yang dihasilkan perusahaan sudah memenuhi komitmennya pada lingkungan, terutama pemenuhan peraturan lingkungan hidup, pencegahan pencemaran serta perbaikan berkelanjutan (Indonesia Environment \& Energy Center (IEC), 2014).

\section{Pengungkapan Lingkungan di Indonesia dan Thailand}

Menurut teori stakeholder, beroperasinya perusahaan bukan hanya untuk kepentingan entitas itu sendiri melainkan juga memberikan suatu manfaat kepada stakeholder-nya. Keberadaan dan keberlanjutan suatu entitas bergantung pada dukungan stakeholder. Pengambilan keputusan dan pembentukan karakteristik di setiap perusahaan oleh stakeholder berbeda meskipun sektor usahanya sama (Kharisma, 2015). Tanggungjawab lingkungan di Asia Tenggara semakin dianggap sebagai suatu keharusan dan norma untuk setiap entitas bisnis (Asean CSR Network, 2016). Kebangsaan atau negara merupakan hal yang perlu dipertimbangkan dalam memahami tingkat pengungkapan lingkungan. Asal negara mempengaruhi tingkat keleluasaan pengungkapan lingkungan hal ini dikarenakan peran peraturan atau perundangundangan yang berbeda di masing-masing negara. Kesadaran masyarakat mengenai masalah lingkungan dan tanggungjawab perusahaan serta etika terhadap lingkungan di masing-masing negara tersebut juga memiliki peran (Kolk, Walhain \& Van de Wateringen, 2001). Didukung dengan hasil penelitian sebelumnya yaitu adanya perbedaan pengungkapan sosial dan lingkungan di dua negara atau lebih (Capple \& Moon, 2005; Kolk, Walhain \& Van de Wateringen, 2001; Supriyono, Almasyhari, 
Suhardjanto \& Rahmawati, 2015; Yusoff \& Lehman, 2006).

H1: Terdapat perbedaan pengungkapan lingkungan di Indonesia dan Thailand

\section{Ukuran Perusahaan dan Pengungkapan Lingkungan Perusahaan}

Menurut Lawer (2013), semakin besarnya perusahaan berarti semakin perusahaan dikenal banyak masyarakat berarti informasi tentang perusahaan semakin mudah didapatkan, karena perusahaan berukuran lebih besar akan mendapatkan pengawasan dari masyarakat serta public demand tentang informasi yang lebih tinggi sehingga akan mengungkapkan lebih banyak informasi. Tekanan perusahaanperusahaan besar akan lebih besar daripada perusahaan-perusahaan kecil, sehingga perusahaan besar akan meningkatkan pengungkapan informasinya sebagai strategi bisnis untuk membangun citra sosial yang baik (Jannah \& Muid, 2014).

Terdapat beberapa alasan positif terkait hubungan yang positif antara ukuran perusahaan dan pengungkapan lingkungan perusahaan, diantaranya pertama akumulasi dan penyebarluasan informasi adalah tanggungjawab mahal, perusahaan kecil mungkin tidak mempunyai sumber daya untuk mengumpulkan banyak informasi serta menyebarkannya ke publik. Kedua yaitu perusahaan yang besar umumnya mengumpulkan informasi bagi kepentingan internal untuk pengambilan keputusan manajerial sehingga informasi telah tersedia dan mudah untuk langsung mengungkapkan informasi. Ketiga, perusahaan besar umumnya tunduk pada harapan publik dan diawasi otoritas pemerintah. Perusahaan ini biasanya memiliki lebih banyak pemegang saham (individu dan kelembagaan). Perusahaan semacam itu percaya adanya wpengungkapan informasi lingkungan akan menciptakan kepercayaan antar pemangku kepentingan dan menurunkan kritik serta tekanan publik dari pemerintah. Sehingga perusahaan besar itu diharapkan bisa mengungkapkan lebih banyak informasi lingkungan daripada perusahaan kecil (Pahuja, 2009). Didukung dengan hasil penelitian sebelumnya yaitu ukuran perusahaan mempunyai pengaruh positif terhadap corporate social responsibility disclosure (Bayoud, Kavanagh dan Slaughter (2012); Chauhan (2014); Marfuah dan Cahyono (2016); Wuttichindanon (2017)). Ukuran perusahaan berpengaruh positif terhadap corporate social and environmental reporting (Gao, Heravi \& Xiao, 2005). Ukuran perusahaan berpengaruh positif terhadap environmental disclosures (Pahuja, 2009).

H2: Ukuran perusahaan berpengaruh positif terhadap pengungkapan lingkungan perusahaan

\section{Umur Perusahaan dan Pengungkapan Lingkungan Perusahaan}

Untari (2010) menyatakan perusahaan lebih tua akan lebih mengerti informasiinformasi apa yang seharusnya diungkapkan pada laporan tahunan perusahaan maka informasi-informasi yang memberi pengaruh positif terhadap perusahaan akan diungkapkan termasuk pengungkapan lingkungan. Pemangku kepentingan perusahaan akan terus belajar dan berusaha dalam menghadapi masalah sesuai dengan pengalaman dalam menghadapi masalah yang terjadi. Semakin tua perusahaan maka perusahaan semakin memperbaiki kualitas dan luas pengungkapan tanggungjawab lingkungan (Pranoto, 2015). Sehingga semakin tua umur perusahaan semakin luas pula informasi pengungkapan pada laporan keuangan tahunan. Didukung dengan hasil penelitian sebelumnya yaitu umur perusahaan berpengaruh positif terhadap corporate social responsibility disclosure (Bayoud, Kavanagh dan Slaughter (2012). Umur perusahaan memiliki pengaruh signifikan terhadap environmental disclosure (Akbas, 2014). Umur perusahaan secara parsial berpengaruh signifikan terhadap pengungkapan corporate social responsibility (Hanny \& Nurfrianto, 2016).

H3: Umur perusahaan berpengaruh positif terhadap pengungkapan lingkungan perusahaan

\section{Profitabilitas dan Pengungkapan Ling- kungan Perusahaan}

Profitabilitas merupakan informasi yang berkaitan dengan laba dalam mengukur kegagalan dan keberhasilan bisnis untuk mencapai tujuan perusahaan yang telah ditetapkan sebelumnya (Octavia, 2012). Menurut Anggraini (2006), profitabilitas yang semakin tinggi maka informasi pengungkapan yang diberikan oleh manajer semakin rinci karena manajer akan meyakinkan investor darimana profitabilitas berasal. Semakin tinggi profitabilitas semakin banyak investor yang menanamkan sahamnya, sehingga tanggungjawab perusahaan mengenai pengungkapan informasi dintuntut semakin luas. Alasan lainnya yaitu bahwa 
pada saat kemampuan perusahaan menghasilkan laba diatas rata-rata industri perusahaan akan mengungkapkan informasi lebih supaya kreditor dan investor yakin posisi perusahaan berada di persaingan yang kuat serta operasi berjalan efisien (Suhardjanto \& Miranti, 2009).

Profitabilitas merupakan faktor yang signifikan untuk menentukan environmental disclosure (Choiriyah, 2010). Sehingga semakin tinggi profitabilitas suatu perusahaan maka pengungkapan lingkungan semakin tinggi. Didukung dengan hasil penelitian sebelumnya yaitu profitabilitas berpengaruh positif terhadap environmental disclosures (Pahuja, 2009). Profitabilitas mempunyai pengaruh positif terhadap corporate social responsibility (Chauhan, 2014). Profitabilitas mempunyai pengaruh signifikan terhadap social and environmental disclosure (Lu \& Abeysekera, 2014). Profitabilitas berpengaruh signifikan terhadap corporate social responsibility disclosure (Sari, 2012). Profitabilitas berpengaruh signifikan terhadap Indonesian environmental reporting index (Suhardjanto \& Miranti, 2009).

H4: Profitabilitas berpengaruh positif terhadap pengungkapan lingkungan perusahaan

\section{ISO 14001 dan Pengungkapan Lingkungan Perusahaan}

Perusahaan yang mendapatkan sertifikasi lingkungan memiliki motivasi untuk perbaikan lingkungan dan menaikkan citra perusahaan dimata stakeholder contohnya dalam penelitian Corbett, Luca dan Pan (2003). Setelah itu diikuti perbaikan dalam informasi pengungkapan lingkungan. Yusoff dan Lehman (2006) menemukan negara Australia lebih banyak melakukan pengungkapan lingkungan dibandingkan Malaysia dikarenakan adanya sertifikasi ISO 14001. Tingginya pengungkapan informasi lingkungan dikarenakan tekanan pihak-pihak eksternal perusahaan dan pasar global. Menurut Supatminingsih (2015) perusahaan yang menerapkan ISO 14001 berarti memiliki suatu komitmen dalam perbaikan yang terus menerus (continual improvement), bertahap dan bersifat conformance (kesesuaian) bukan performance (kinerja). Perusahaan yang bersertifikasi berharap produknya mempunyai reputasi tinggi, dan dapat diterima oleh stakeholdernya dengan baik. Sehingga diharapkan perusahaan yang bersertifikasi melaksanakan pengungkapan lingkungan yang tinggi.

H5: ISO 14001 berpengaruh positif terhadap pengungkapan lingkungan perusahaan

\section{METODE PENELITIAN \\ Populasi dan Sampel}

Studi ini mengambil populasi keseluruhan perusahaan pertambangan pada Bursa Efek Indonesia (BEI) dan Bursa Efek Thailand (SET). Perusahaan pertambangan dipilih sebagai sampel karena sekitar 70 persen penyebab kerusakan lingkungan adalah kegiatan pertambangan. Negara Asia Tenggara dipilih karena menurut data WHO merupakan kawasan rentan peningkatan pencemaran udara, khususnya Indonesia dan Thailand termasuk negara dengan tingkat emisi karbon tertinggi, dan memiliki jumlah perusahaan pertambangan terbanyak dibandingkan negara Asia Tenggara lainnya sehingga dapat mewakili populasi. Studi ini menggunakan metode purposive sampling, syarat dalam pengambilan sampel meliputi.

1. Perusahaan pertambangan yang masing -masing terdaftar di Bursa Efek Indonesia (BEI) dan Bursa Efek Thailand (SET) periode 2014-2016.

2. Perusahaan pertambangan yang menyediakan laporan tahunan pada tahun 2014-2016.

3. Perusahaan pertambangan yang secara eksplisit melaporkan telah melakukan pengungkapan lingkungan perusahaan pada laporan tahunan atau sustainability report dan memiliki informasi lengkap sesuai variabel yang

Tabel 1.

Populasi dan Sampel

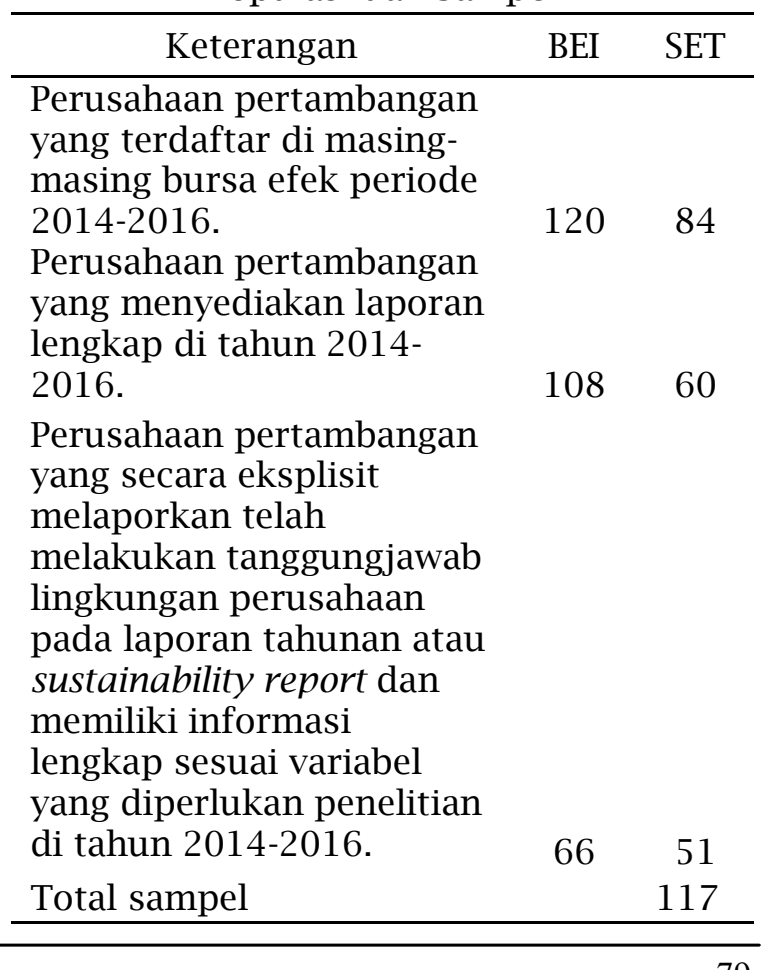


diperlukan penelitian di tahun 20142016.

Penelitian ini menggunakan data sekunder bersumber dari Bursa Efek Indonesia (BEI) dan Bursa Efek Thailand (SET) tahun 2014-2016. Data diperoleh dari www.idx.co.id dan www.set.or.th. Sampel yang memenuhi kriteria pengambilan sampel secara purposive sampling yaitu 22 perusahaan pertambangan atau 66 data di BEI dan 17 perusahaan pertambangan atau 51 data di SET.

\section{Definisi Operasional dan Pengukuran Variabel}

Pengungkapan lingkungan perusahaan adalah variabel dependen pada penelitian ini. Pengungkapan lingkungan diukur menggunakan analisis isi (content analysis) mengacu pada Indonesian Environmental Reporting (IER) Index dari Global Reporting Initiatives (GRI)-G4 mengenai item pengungkapan lingkungan. Pengungkapan lingkungan menurut GRI-G4 membagi kategori lingkungan menjadi 12 aspek, yaitu energi, air, bahan, keanekaragaman hayati, efluen dan limbah, emisi, produk dan jasa, transportasi, kepatuhan, lain-lain, asesmen pemasok atas lingkungan, dan mekanisme pengaduan masalah lingkungan.

$$
\operatorname{IEDj}=\left(\sum X \mathrm{Xij}\right) / \mathrm{Nj}
$$

Catatan : IEDj=indeks environmental disclosure perusahaan j; $\quad \Sigma \mathrm{X} i \mathrm{j}=\mathrm{dummy}$ variabel, skor bernilai 1 apabila item i diungkapkan, skor bernilai 0 apabila item tidak diungkapkan; $\mathrm{N} j=\mathrm{jumlah}$ keseluruhan item pada perusahaan $\mathrm{j}$ (34 item indikator GRI-G4).

Variabel independen ukuran perusahaan akan diproksikan dengan total aset. Penelitian ini menggunakan proksi total aset untuk menghitung ukuran perusahaan karena berisi keseluruhan aset lancar maupun tetap sehingga menggambarkan ukuran perusahaan sebenarnya (Suhardjanto \& Choiriyah, 2010). Umur perusahaan diperoleh dari tahun pendirian organisasi sampai dengan periode penelitian (Alsaeed, 2006).

Rasio Return on Asset (ROA) mengukur kemampuan perusahaan untuk menghasilkan laba. Menurut Darsono (2005) ROA perusahaan dapat menunjukkan apakah perusahaan efisien dalam menggunakan aktiva untuk kegiatan operasionalnya. Data ROA dapat diperoleh dari laporan laba rugi untuk Earning Before Interest and Tax (EBIT) dan neraca untuk total aset. Rumus untuk mencari ROA ada- lah Earning Before Interest and Tax (EBIT) dibagi total aset (Irawati, 2006). Pengukuran ISO 14001 dengan variabel dummy diberi skor bernilai 1 bagi perusahaan bersertifikasi ISO 14001 dan skor bernilai 0 bagi perusahaan yang tidak bersertifikasi ISO 14001.

\section{Model penelitian}

Penelitian ini menggunakan statistik deskriptif, uji perbedaan, dan uji pengaruh pada data gabungan Indonesia dan Thailand. Pertama yaitu statistik deskriptif menyajikan gambaran dari sampel dari nilai rata-rata (mean), standar deviasi, maksimum, dan minimum. Kedua yaitu uji perbedaan menggunakan Independent Sampels $t$ Test untuk membandingkan tingkat pengungkapan lingkungan di annual report atau sustainability report perusahaan pertambangan negara Indonesia dan Thailand. Ketiga yaitu uji pengaruh pada variabel independen terhadap variabel dependen untuk mengetahui faktor-faktor yang mempengaruhi pengungkapan lingkungan perusahaan pertambangan negara Indonesia dan Thailand dengan regresi linier berganda. Selanjutnya, penelitian ini akan menguji pengaruh dari variabel independen terhadap variabel dependen di masing-masing negara Indonesia dan Thailand agar mendapatkan hasil yang maksimal. Pengaruh variabel independen terhadap dependen sebagai pengujian hipotesis menggunakan rumus yaitu:

$\mathrm{ED}=\alpha+\beta_{1} \mathrm{SIZE}+\beta_{2} \mathrm{AGE}+\beta_{3} \mathrm{ROA}+\beta_{4} \mathrm{ISO}+\varepsilon$

Catatan : ED (Pengungkapan Lingkungan) $=$ angka 1 untuk item yang diungkapkan dan angka 0 untuk item yang tidak diungkapkan dan dihitung presentasenya; SIZE (Ukuran Perusahaan)=total aset; AGE (Umur Perusahaan)=sejak perusahaan berdiri sampai periode penelitian; ROA (Return on Assets)=EBIT/total aset; ISO (ISO 14001)=dummy variabel, angka 1 untuk perusahaan bersertifikasi ISO 14001 dan angka 0 untuk perusahaan tidak bersertifikasi ISO 14001.

Penelitian sebelumnya biasanya dilakukan pada satu negara saja sehingga tidak dapat diketahui perbandingan kondisi karakteristik perusahaan dan sertifikasi ISO 14001 negara tersebut dengan negara lain. Penelitian berdasarkan data yang berhubungan dengan kondisi lingkungan seperti pencemaran udara dan peningkatan karbon penting dalam pemilihan sampel penelitian agar diketahui negara mana saja 
yang rentan terhadap lingkungan sehingga tanggungjawab lingkungan menjadi kebutuhan.

\section{ANALISA DAN PEMBAHASAN Analisis Deskriptif}

Tabel 2 merupakan hasil statistik deskriptif data Indonesia dan Thailand yaitu nilai minimum, nilai maksimum, nilai rata-rata (means), dan standar deviasi.

Berdasarkan Tabel 2 dapat diketahui jumlah sampel (N) gabungan negara Indonesia dan Thailand adalah 117 data dengan tingkat pengungkapan lingkungan memiliki nilai rata-rata (mean) $28,47 \%$ dan standar deviasi 26,28\%. Perusahaan pertambangan Indonesia yaitu Bukit Asam Tbk melakukan pengungkapan lingkungan tertinggi yaitu 34 item sesuai GRI G4 sebesar $100 \%$. Perusahaan pertambangan Thailand yaitu Banpu Public Company Limited dan Gunkul Engineering Public Company Limited melakukan pengungkapan lingkungan terendah yaitu tidak sesuai GRI G4. Hal ini menunjukkan pengungkapan lingkungan di kedua negara masih rendah. Ukuran perusahaan kedua negara yang diukur dengan total aset perusahaan memiliki nilai rata-rata atau mean yaitu Rp 9.964.692.408.559.203.000 dan nilai standar deviasi Rp 52.658.670.924.987.590.000. Perusahaan pertambangan Indonesia yaitu Vale Indonesia Tbk memiliki nilai tertinggi dengan total asset sebesar Rp 5.553.983.600.908.000. Perusahaan pertambangan Indonesia yaitu Benakat Integra Tbk memiliki nilai terendah dengan total asset sebesar $\mathrm{Rp}$ 1.428.806.851. Umur perusahaan pertambangan di negara Indonesia dan Thailand memiliki nilai rata-rata (mean) sebesar 28,53 dibulatkan menjadi 29 tahun dan standar deviasi 13,98. Perusahaan pertambangan Indonesia yaitu PT Timah Tbk memiliki umur tertinggi yaitu 55 tahun, perusahaan sudah berdiri sejak 1961. Perusahaan pertambangan Thailand yaitu
Global Power Synergy Public Company Limited memiliki umur terendah yaitu 1 tahun, perusahaan sudah berdiri sejak 2013.

Profitabilitas kedua negara dalam penelitian dihitung dengan ROA mempunyai nilai rata-rata (mean) yaitu $6,94 \%$ dan nilai dari standar deviasi 10,41. ROA tertinggi memiliki nilai sebesar 43,71\%. ROA terendah memiliki nilai sebesar $46,77 \%$. Perusahaan pertambangan Indonesia yaitu PT Mitrabara Adiperdana Tbk memiliki ROA tertinggi dengan tingkat laba sebelum bunga dan pajak sebesar Rp 47.718.137 dengan total asset sebesar Rp 109.163.029 pada tahun 2015. Perusahaan pertambangan Indonesia yaitu Bumi Resources Tbk memiliki ROA terendah karena mengalami kerugian dengan tingkat rugi sebelum bunga dan pajak sebesar Rp 1.587.340.824 dengan total asset sebesar Rp 3.394.276.258 pada tahun 2015. ISO 14001 perusahaan pertambangan kedua negara dihitung menggunakan variabel dummy memiliki nilai rata-rata (mean) sebesar 0,44 berarti jumlah perusahaan pertambangan di Indonesia dan Thailand yang bersertifikasi lingkungan ISO 14001 masih rendah dengan standar deviasi 0,50. ISO 14001 memiliki nilai tertinggi sebesar 1 , yaitu terdapat 52 data perusahaan yang mendapatkan sertifikasi ISO 14001. ISO 14001 memiliki nilai terendah 0, yaitu terdapat 65 data perusahaan yang tidak mendapatkan sertifikasi ISO 14001.

Tabel 3 menunjukkan hasil output pada nilai Sig. (2-tailed) dengan nilai $0,000<0,05$ hal ini menunjukkan negara Indonesia dan Thailand memiliki tingkat pengungkapan lingkungan yang berbeda, sehingga hipotesis pertama adanya perbedaan pengungkapan lingkungan perusahaan pertambangan di negara Indonesia dan Thailand diterima.

Adanya perbedaan tingkat pengungkapan di kedua negara yaitu di Indonesia dan Thailand hal ini disebabkan perbedaan regulasi atau peraturan di

Tabel 2.

Statistik Deskriptif

\begin{tabular}{lrllll}
\hline & $\mathbf{N}$ & \multicolumn{1}{c}{ Minimum } & \multicolumn{1}{c}{ Maximum } & \multicolumn{1}{c}{ Mean } & \multicolumn{1}{c}{ Std. Deviation } \\
\hline ED (\%) & 117 &, 000 & 100,000 & 28,47350 & 26,279008 \\
SIZE & 117 & 1428806851 & $5,554 \mathrm{E}+20$ & $9,96469 \mathrm{E}+$ & $5,265867 \mathrm{E}+19$ \\
AGE & 117 & 1,000 & 55,000 & 28,52991 & 13,984950 \\
ROA (\%) & 117 & $-46,765$ & 43,713 & 6,94044 & 10,412935 \\
ISO & 117 &, 000 & 1,000 &, 44444 & \multirow{2}{*}{499041} \\
Valid N (listwise) & 117 & & & & \\
\hline
\end{tabular}


masing-masing negara, selain itu kebijakan pemerintah juga berperan. Kesadaran dari masing-masing perusahaan yang tidak hanya mengambil sumber daya alam sebagai bahan baku tetapi memberikan timbal balik, menjaga, dan melestarikan lingkungan juga berperan penting. Karakteristik masing-masing perusahaan yang berbeda sehingga tingkat pengungkapan perusahaan juga berbeda. Masyarakat dan budaya masing-masing negara mengenai kesadaran dan kebiasaan untuk mengelola lingkungan dengan baik menjadi faktor yang mendukung adanya perbedaan tingkat pengungkapan lingkungan dikedua negara tersebut. Perbedaan tingkat pengungkapan lingkungan terdapat pada jumlah score berdasarkan item-item pengungkapan lingkungan yang diterbitkan GRI G4. Hasil uji beda pengungkapan lingkungan negara Indonesia menghasilkan nilai mean rank sebesar 46,11 dan pengungkapan lingkungan negara Thailand menghasilkan nilai mean rank sebesar 75,69. Hasil perbedaan tersebut menunjukkan nilai pengungkapan lingkungan di negara Thailand lebih besar, sehingga dapat disimpulkan perusahaan pertambangan di negara Thailand lebih peduli terhadap lingkungan. Hal ini mendukung penelitian Loh, Thao, Sim, Thomas dan Yu. (2016) yaitu Thailand memiliki tingkat pengungka- pan tertinggi dan satu-satunya negara yang memiliki pengungkapan rata-rata negara ASEAN lainnya karena budaya bisnis tentang kepatuhan yang tinggi dan memasukkan tanggungjawab sosial dan lingkungan pada visi misi perusahaan.

\section{Pengujian Hipotesis}

Tabel 4 menunjukkan nilai adjusted $R^{2}$ sebesar 0,289. Berdasarkan nilai tersebut menunjukkan bahwa kemampuan variabel independen meliputi ukuran perusahaan, umur perusahaan, profitabilitas, serta ISO 14001 dalam menjelaskan variabel dependen yaitu luas pengungkapan lingkungan adalah 28,9\% dan sisanya 71,1\% dijelaskan faktor-faktor yang lainnya di luar model. Hasil pengolahan data diperoleh nilai F hitung adalah 10,228 dengan probabilitasnya $0,000<0,05$ menunjukkan ukuran perusahaan, umur perusahaan, profitabilitas, dan ISO 14001 secara bersama berpengaruh terhadap pengungkapan lingkungan pada perusahaan pertambangan di negara Indonesia dan Thailand. Hasil uji F memperlihatkan bahwa penelitian ini fit atau layak. Hasil pengujian hipotesis dapat disimpulkan bahwa variabel independen ukuran perusahaan, umur perusahaan, serta ISO 14001 mempunyai pengaruh positif terhadap pengungkapan lingkungan perusahaan pertambangan di Indonesia

Tabel 3.

Hasil Uji Perbedaan

\begin{tabular}{lrcccc}
\hline \multicolumn{2}{c}{ Test Statistics $^{\mathbf{a}}$} & \multicolumn{3}{c}{ Ranks } \\
\hline & \multicolumn{1}{c}{ ED } & Kategori & $\mathrm{N}$ & Mean Rank & $\begin{array}{c}\text { Sum of } \\
\text { Ranks }\end{array}$ \\
Mann-Whitney U & 832,000 & 1.00 & 66 & 46,11 & 3043.00 \\
Wilcoxon W & 3043,000 & 2.00 & 51 & 75,69 & 3860.00 \\
Z & $-4,697$ & Total & 117 & & \\
Asymp. Sig. (2-tailed) &, 000 & & & & \\
\hline
\end{tabular}

a. Grouping Variable: Negara

Tabel 4.

Hasil Uji Regresi Berganda

\begin{tabular}{|c|c|c|c|}
\hline Variabel & Koefisien & $t$ & Sig. \\
\hline $\begin{array}{l}\text { (Constant) } \\
\text { Size (log) } \\
\text { Age } \\
\text { ROA (\%) } \\
\text { ISO } \\
\text { R Square } \\
\text { Adjusted R Square } \\
\text { F } \\
\text { Sig } \\
\text { Keterangan: } \\
\text { (*) Signifikan 5\% }\end{array}$ & $\begin{array}{c}-1,324 \\
0,047 \\
, 003 \\
, 002 \\
, 091 \\
, 320 \\
, 289 \\
10,228 \\
, 000\end{array}$ & $\begin{array}{c}-4,259 \\
4,485 \\
2,404 \\
, 945 \\
2,174\end{array}$ & $\begin{array}{c}, 000^{*} \\
, 0000^{*} \\
, 018^{*} \\
347^{*} \\
032^{*}\end{array}$ \\
\hline
\end{tabular}


dan Thailand. Variabel independen lainnya yaitu profitabilitas tidak memiliki pengaruh yang signifikan terhadap pengungkapan lingkungan perusahaan pertambangan di negara Indonesia dan Thailand.

Berdasarkan uji regresi linier berganda hasil uji t memperlihatkan nilai signifikansi ukuran perusahaan yaitu 0,000 $<0,05$ dan koefisien regresi 0,047 dapat dikatakan ukuran perusahaan memiliki pengaruh positif signifikan terhadap pengungkapan lingkungan. Kesimpulannya yaitu hipotesis yang menyatakan ukuran perusahaan memiliki pengaruh positif terhadap pengungkapan lingkungan perusahaan di negara Indonesia dan Thailand diterima. Hasil penelitian ini didukung oleh Pahuja (2009) yaitu akumulasi dan penyebarluasan informasi merupakan tanggungjawab yang tidak murah sehingga bagi perusahaan kecil dimungkinkan untuk mengumpulkan informasi dan menyebarkannya ke publik tidak memiliki sumber daya. Perusahaan besar umumnya mengumpulkan informasi untuk kepentingan internal untuk pengambilan keputusan manajerial sehingga informasi telah tersedia dan mudah untuk langsung mengungkapkan informasi. Perusahaan besar umumnya tunduk pada harapan publik dan diawasi oleh otoritas pemerintah. Perusahaan tersebut biasanya memiliki lebih banyak pemegang saham (individu dan kelembagaan). Perusahaan semacam itu mempercayai pengungkapan informasi lingkungan akan menciptakan kepercayaan antar pemangku kepentingan serta mengurangi kritik serta tekanan publik dari pemerintah. Perusahaan-perusahaan yang lebih besar menghadapi tekanan besar daripada perusahaan-perusahaan kecil, maka mereka akan meningkatkan pengungkapan informasi perusahaan untuk membangun citra sosial yang baik sebagai bagian dari strategi bisnis mereka (Jannah \& Muid, 2014). Hasil penelitian ini tidak sesuai dengan penelitian Maiyarni, Susfayetti, dan Erwati (2014) dimana perusahaan besar tidak selalu melakukan pengungkapan lingkungan yang lebih luas untuk mendapatkan pengaruh kepentingan dari stakeholder internal dan eksternal dikarenakan pengungkapan merupakan kewajiban yang bisa mempengaruhi kelangsungan hidup perusahaan serta bukan hanya sebuah kegiatan

Hasil uji t menunjukkan signifikansi umur perusahaan $0,018<0,05$ dengan koefisien regresi 0,003 dapat dikatakan umur perusahaan berpengaruh positif signifikan terhadap pengungkapan lingkungan. Kesimpulannya hipotesis ketiga umur perusahaan memiliki pengaruh positif terhadap pengungkapan lingkungan perusahaan di negara Indonesia dan Thailand diterima. Hasil penelitian ini didukung oleh Akbas (2014) yaitu perusahaan yang lebih tua akan mengungkapkan informasi-informasi yang berpengaruh positif bagi perusahaan termasuk pengungkapan lingkungan karena mungkin lebih mengerti mengenai informasi-informasi apa saja yang seharusnya diungkapkan dalam laporan tahunan perusahaan. Para pemangku kepentingan perusahaan akan terus belajar dan berusaha dalam menghadapi masalah sesuai dengan seberapa pengalaman dalam menghadapi masalah yang terjadi. Semakin tua perusahaan maka perusahaan semakin memperbaiki kualitas dan luas pengungkapan tanggungjawab lingkungan. Menurut Pranoto (2015) para pemangku kepentingan perusahaan akan terus belajar dan berusaha dalam menghadapi masalah sesuai dengan seberapa pengalaman dalam menghadapi masalah yang terjadi. Semakin tua perusahaan maka perusahaan semakin memperbaiki kualitas dan luas pengungkapan tanggungjawab lingkungan.

Hasil uji t menunjukkan signifikansi profitabilitas 0,347>0,05 dengan koefisien regresi 0,002 dapat dikatakan profitabilitas tidak memiliki berpengaruh terhadap pengungkapan lingkungan. Kesimpulannya hipotesis keempat profitabilitas memiliki pengaruh positif terhadap pengungkapan lingkungan perusahaan di negara Indonesia dan Thailand ditolak. Hasil penelitian ini berbeda dengan hasil penelitian sebelumnya oleh Suhardjanto dan Miranti (2009) yaitu perusahaan akan mengungkapkan informasi lebih ketika kemampuan menghasilkan labanya berada diatas ratarata industri agar investor dan kreditor yakin bahwa perusahaan berada dalam posisi persaingan yang kuat dan operasi perusahaan berjalan efisien dan mendukung penelitian Purwanto (2011) yaitu tingkat ROA yang tinggi pada perusahaan belum tentu dananya dialokasikan untuk kegiatan lingkungan dan sosial sehingga tingkat tanggungjawab perusahaan berkaitan dengan lingkungan dan sosial masih rendah. Menurut Capaldi (2005) hubungannya keleluasaan pengungkapan dengan profitabilitas dipengaruhi oleh cara pandang perusahaan terhadap pengungkapan tersebut. Ada beberapa perusahaan yang menganggap bahwa 
pengungkapan sebagai pengurang laba dan beberapa yang berpandangan sebaliknya.

Hasil uji t menunjukkan signifikansi

ISO 14001 sebesar $0,032<0,05$ dengan koefisien regresi 0,091 dapat dikatakan ISO 14001 berpengaruh positif signifikan terhadap pengungkapan lingkungan. Jadi dapat disimpulkan bahwa hipotesis kelima ISO 14001 berpengaruh positif terhadap pengungkapan lingkungan perusahaan di negara Indonesia dan Thailand diterima. Hasil ini didukung penelitian Supatminingsih (2015) yaitu perusahaan yang menerapkan ISO 14001 berarti berkomitmen melakukan suatu perbaikan terus menerus (continual improvement), bertahap dan bersifat conformance (kesesuaian) bukan performance (kinerja). Perusahaan yang telah bersertifikasi berharap produknya mempunyai reputasi tinggi dan dapat diterima oleh stakeholdernya dengan baik. Sehingga perusahaan yang bersertifikasi ISO 14001 melakukan pengungkapan lingkungan yang tinggi. Yusoff dan Lehman (2006) mengenai komparatif negara Malaysia dan Australia dimana kedua negara tersebut melakukan pengungkapan yang lebih luas dikarenakan ISO 14001. ISO 14001 memotivasi perusahaan untuk memperbaiki lingkungan karena perusahaan yang mendapatkan sertifikasi ISO 14001 mempunyai komitmen terhadap lingkungan. Hasil penelitian berbeda dengan hasil penelitian sebelumnya oleh Dianawati (2017) yaitu pada penelitiannya tidak adanya perbedaan luas pengungkapan perusahaan yang mendapat sertifikasi dan tidak mendapat sertifikasi.

\section{SIMPULAN DAN IMPLIKASI Simpulan}

Berdasarkan hasil uji perbandingan dan uji pengaruh dapat disimpulkan bahwa sesuai tujuan penelitian pertama bahwa uji perbandingan menunjukkan tingkat pengungkapan lingkungan perusahaan pertambangan di negara Indonesia dan Thailand berbeda secara signifikan. Tujuan penelitian kedua dan ketiga yaitu menguji pengaruh karakteristik perusahaan yaitu ukuran perusahaan, umur perusahaan, dan profitabilitas, serta ISO 14001 terhadap pengungkapan lingkungan. Hasil penelitian secara umum didapatkan ukuran perusahaan, umur perusahaan, dan ISO 14001 memiliki pengaruh positif signifikan terhadap pengungkapan lingkungan perusahaan. Adapun profitabilitas tidak memiliki pengaruh terhadap pengungkapan lingkungan perusahaan pertambangan di Indonesia dan Thailand. Pengujian pada negara
Indonesia umur perusahaan dan ISO 14001 berpengaruh positif signifikan terhadap pengungkapan lingkungan perusahaan, ukuran perusahaan, dan profitabilitas tidak berpengaruh terhadap pengungkapan lingkungan perusahaan. Hasil uji pada negara Thailand menunjukkan ukuran perusahaan dan umur perusahaan memiliki pengaruh positif signifikan terhadap pengungkapan lingkungan perusahaan sedangkan profitabilitas dan ISO 14001 tidak memiliki pengaruh terhadap pengungkapan lingkungan perusahaan.

\section{Implikasi}

Hasil penelitian ini menunjukkan bahwa terdapat perbedaan pengungkapan lingkungan negara Indonesia dan Thailand serta pengungkapan lingkungan negara Indonesia lebih rendah dibandingkan negara Thailand. Hal ini mengandung implikasi agar kedepannya pihak perusahaan di Indonesia lebih memperbaiki dan meningkatkan perhatiannya terhadap lingkungan yang dapat meningkatkan tanggungjawabnya terhadap lingkungan sehingga tujuan perusahaan dapat tercapai karena perlunya keseimbangan ekonomi, sosial, dan lingkungan perusahaan. Karakteristik perusahaan dapat berbeda-beda disetiap perusahaan meskipun perusahaan tersebut bergerak pada jenis usaha yang sama. Hasil penelitian menunjukkan bahwa pengaruh ukuran perusahaan, umur perusahaan, profitabilitas, dan ISO 14001 terhadap pengungkapan lingkungan masing-masing negara berbeda. Hal ini mengandung implikasi agar perusahaan kedepannya terus membangun budaya bisnis kepatuhan terhadap peraturan sehingga masing-masing perusahaan dengan masing-masing karakteristiknya secara sadar melaksanakan kewajiban tanggungjawab lingkungan.

\section{KETERBATASAN DAN SARAN \\ Keterbatasan}

Keterbatasan penelitian ini adalah penelitian tidak meneliti kualitas pengungkapan lingkungan perusahaan melainkan kuantitas pengungkapan lingkungan perusahaan, sehingga diantara perusahaan yang mengungkapkan mendetail dibandingkan perusahaan yang mengungkapkan secara tidak mendetail tidak adanya perbedaan score yang menyebabkan subyektifitas dalam penentuan pengukuran indeks GRI G4 terutama penentuan indeks pada annual report perusahaan. 


\begin{abstract}
Saran
Saran berdasarkan hasil penelitian ini yaitu peneliti selanjutnya diharapkan menggunakan metode scoring untuk menghindari subyektifitas pengukuran indeks terutama pada annual report yang penentuan indeksnya berdasarkan pemahaman peneliti.
\end{abstract}

\section{DAFTAR PUSTAKA}

Akbar, Y.C. (2015). Pengungkapan tanggung jawab sosial perusahaan dan karakteristik perusahaan: Studi komparasi perusahaan manufaktur Indonesia-Thailand (Skripsi). Universitas Sebelas Maret, Fakultas Ekonomi dan Bisnis, Surakarta.

Akbas, H.E. (2014). Company characteristics and environmental disclosure: An empirical investigation on companies listed on borsa sstanbul 100 index. Muhasebe ve Finansman Dergisi, (62).

Alsaeed, K. (2006). The association between firm-specific characteristics and disclosure: The case of Saudi Arabia. Managerial Auditing Journal, 21(5), 476-496.

Anggraini, F.R.R. (2006). Pengungkapan informasi sosial dan faktor-faktor yang mempengaruhi pengungkapan informasi sosial dalam laporan keuangan tahunan (Studi empiris pada perusahaan-perusahaan yang terdaftar Bursa Efek Jakarta). Paper dipresentasikan pada acara Simposium Nasional Akuntansi IX, Padang.

Asean CSR Network. (06 September 2016). In Southeast Asia, corporate governance picks up as a norm. Diakses dari https:/www.asean-csr-network.org.

Bani-Khalid, T., \& Kouhy, R. (2017). The impact of national contextual factors on corporate social and environmental disclosure (CSED): The perceptions of jordanian stakeholder. International Review of Management and Business Research, 6(2), 556.

Bayoud, N.S., Kavanagh, M., \& Slaughter, G. (2012). Factors influencing levels of corporate social responsibility disclosure Libyan firms: A mixed study. International Journal of Economics and Finance, 4(4), 13-29.

Budiarti, M., \& Raharjo, S.T. (2017). Corporate social responsibility (CSR) dari sudut pandang perusahaan. Share Social Work Journal, 4(1).

Capaldi, N. (2005). Corporate social responsibility and the bottom line.
International Journal of Social Economics, 32(5), 408-423.

Capple, W., \& Moon, J. (2005). Corporate social responsibility (CSR) in Asia a seven-country study of CSR web site reporting. Business \& Society, 44(4), 415-441.

Chauhan, S. (2014). A relational study of firm's characteristics and CSR expenditure. Procedia Economics and Finance, 11, 23-32.

Choiriyah, U. (2010). Information GAP pengungkapan lingkungan hidup di Indonesia (Thesis). Universitas Sebelas Maret.

Corbett, C.J., Luca, A.M., \& Pan, J. (2003). Global perspectives on global standards. ISO Management Systems, 1, 31-40.

Darsono, A. (2005). Pedoman praktis memahami laporan keuangan. Yogyakarta: Andi.

De Villiers, C., \& Van Staden, C.J. (2010). Shareholders' requirements for corporate environmental disclosures: A cross country comparison. The British Accounting Review 42(4), 227 240.

Dianawati, W. (2017). Pengaruh karakteristik perusahaan dan sertifikasi lingkungan terhadap pengungkapan Corporate Social Responsibility (CSR) di Indonesia. EKUITAS (Jurnal Ekonomi dan Keuangan), 20(2), 226-241.

Elkington, J. (1998). Cannibals with forks: The triple bottom line in 21st century business, gabriola island. BC: New Society Publishers.

Gao, S.S., Heravi, S., \& Xiao, J.Z. (2005). Determinants of corporate social and environmental reporting in Hong Kong: A research note. Accounting Forum,-29(2), 233-242. Elsevier.

Gray, R. (1992). Accounting and environmentalism: an exploration of the challenge of gently accounting for accountability, transparency and sustainability. Accounting, Auditing \& Accountability Journal, 17(5), 399425.

GRI. (2013). Sustainability reporting guidelines. Diakses dari https:// www.globalreporting.org pada tanggal 14 November 2017.

Hadi, N. (2011). Corporate Social Responsibility. Yogyakarta: Graha Ilmu.

Hanny, R. \& Nurfrianto A.F. (2016). Pengaruh karakteristik perusahaan terhadap pengungkapan corporate 
social responsiblity. Jurnal Ilmu Administrasi, 13(3), 547-560.

Hoq, M.Z., Saleh, M., \& Zubayer, M. (2010). The effect of CSR disclosure on institutional ownership. Pakistan Journal of Commerce and Social Sciences, 4(1), 22-39.

Howes, S., \& Wyrwoll, P. (2012). Climate change mitigation and green growth in developing Asia. Asian Development Bank Institute Working Paper No. 369, Australian National University.

Ikatan Akuntan Indonesia (IAI). (2009). Pernyataan Standar Akuntansi Keuangan (PSAK) Nomor 1 Paragraf 9: Penyajian laporan keuangan. Jakarta: Salemba Empat.

Indonesia Environment \& Energy Center (IEC). (23 Juni 2014). ISO 14001 environmental management system. Diakses dari https://environtmenindonesia.com.

Irawati, S. (2006). Manajemen keuangan. Bandug: Pustaka.

Jannah, R., \& Muid, D. (2014). Analisis faktor-faktor yang mempengaruhi carbon emission disclosure pada perusahaan di Indonesia (Studi empiris pada perusahaan yang terdaftar di Bursa Efek Indonesia periode 2010-2012) (Thesis). Universitas Diponegoro, Fakultas Ekonomika dan Bisnis, Semarang.

Kamil, A., \& Herusetya, A. (2012). Pengaruh karakteristik perusahaan terhadap luas pengungkapan kegiatan corporate social responsibility. Media Riset Akuntansi, 2(1).

Kharisma, M.R. (2015). Corporate environmental disclosure pada perusahaan manufaktur dan pertambangan. (Studi pada perusahaan di Indonesia dan Thailand) (Thesis). Universitas Sebelas Maret, Surakarta.

Kolk, A., Walhain, S., \& Van de Wateringen, S. (2001). Environmental reporting by the fortune global 250: Exploring the influence of nationality and sector. Business Strategy and the Environment, 10(1), 15-28.

Kosasih, D. (30 Maret 2016). Greenpeace rilis kerusakan lingkungan akibat tambang di Kalimantan Timur. https://www.greeners.co.

Lavinda. (07 November 2017). PTTEP mengaku kasus dugaan pencemaran hambat investasi. https:// www.cnnindonesia.com.

Lawer, C. (2013). Pengaruh karakteristik perusahaan terhadap pengungkapan tanggung jawab sosial. Jurnal Ekonomi, 19(02).

Lin, L.W. (2009). Corporate social and environmental disclosure in emerging securities markets. NCJ Int'l L. \& Com. Reg., 35, 1.

Loh, L., Thao, N.T.P., Sim, I., Thomas, T., \& $\mathrm{Yu}$, W. (2016). Pelaporan yang Berkelanjutan di Asean Tingkat Kemajuan di Indonesia, Malaysia, Singapura dan Thailand 2015. Centre of Governance, Institutions, and Organisations NUS Bussiness School.

Lu, Y., \& I. Abeysekera (2014). Stakeholders' power, corporate characteristics, and social and environmental disclosure: Evidence from China. Journal of Cleaner Production, 64, 426-436.

Maharani, D. (13 Mei 2016). WHO: Polusi udara di Asia Tenggara makin parah. Diakses dari http:// www.kesehatan.kontan.co.id.

Maiyarni, R., Susfayetti, \& Erwati, M. (2014). Pengaruh profitabilitas, ukuran perusahaan, likuiditas, dan leverage terhadap pengungkapan corporate social responsibility (CSR) pada perusahaan LQ-45 yang terdaftar di bursa efek Indonesia periode 20092012. Jurnal Cakrawala Akuntansi, 6 (1), 79-94.

Marfuah, M., \& Cahyono, Y.D. (2016). Karakteristik perusahaan dan pengungkapan tanggung jawab sosial. Jurnal Akuntansi dan Auditing Indonesia, 15(1).

Nor, N.M., Bahari, N.A.S., Adnan, N.A., Kamal, S.M.Q.A.S., \& Ali, I.M. (2016). The effects of environmental disclosure on financial performance in Malaysia. Procedia Economics and Finance, 35, 117-126.

Octavia, I. (2012). Pengaruh pengungkapan lingkungan terhadap nilai perusahaan dengan profitabilitas sebagai variabel moderasi (Skripsi). Akuntansi Universitas Indonesia, Depok.

Pahuja, S. (2009). Environmental accounting and reporting: Theory, law and empirical evidence. New Century.

Paramitha, B.W., \& Rohman, A. (2014). Pengaruh karakteristik perusahaan terhadap enviromental disclosure. Diponegoro Journal of Accounting, 188-198.

Pranoto, K.P.T. (2015). Pengaruh likuiditas, profitabilitas, ukuran perusahaan, jenis industri, leverage, dan umur 
listing terhadap pelaporan keuangan melalui internet financial reporting (Thesis). STIE Perbanas Surabaya.

Purwanto, A. (2011). Pengaruh tipe industri, ukuran perusahaan, profitabilitas, terhadap corporate social responsibility. Jurnal Akuntansi dan Auditing, 8(1), 12-29.

Republik Indonesia. 2007. Undang-Undang Nomor 40 Tahun 2007 tentang Perseroan Terbatas.

Rosiana G.A.M.E., Juliarsa, G., \& Sari, M.M.R. (2013). Pengaruh pengungkapan CSR terhadap nilai perusahaan dengan profitabilitas sebagai variabel pemoderasi. E-Jurnal Akuntansi, 5(3), 723-728.

Rujivanarom, P. (06 Juni 2017). Govt failing on environment, efforts to curb pollution: Report. https:// www.nationmultimedia.com.

Santioso, L., \& Chandra, E. (2012). Pengaruh profitabilitas, ukuran perusahaan, leverage, umur perusahaan, dan dewan komisaris independen dalam pengungkapan corporate social responsibility. Jurnal Bisnis dan Akuntansi, 14(1), 17-30.

Sari, R.A. (2012). Pengaruh karakteristik perusahaan terhadap corporate social responsibility disclosure pada perusahaan manufaktur yang terdaftar di bursa efek Indonesia. Jurnal Nominal, 1(1).

Suhardjanto, D., \& Miranti, L (2009). Indonesian environmental reporting index dan karakteristik perusahaan. Jurnal Akuntansi dan Auditing Indonesia, 13(1).

Suhardjanto, D., \& Choiriyah, U. (2010). Information GAP: Demand supply environmental disclosure di Indonesia. Jurnal Keuangan dan Perbankan, 14(1), 36-51.

Supatminingsih, S. (2015). Corporate governance dan pengungkapan lingkungan berdasarkan ISO $14001 \mathrm{di}$ Indonesia. Jurnal Akuntansi dan Pajak, 15(02).

Supriyono, E., Almasyhari, A. K., Suhardjanto, D., \& Rahmawati, S. (2015). The impact of corporate governance on corporate social disclosure: comparative study in South East Asia. International Journal of Monetary Economics and Finance, 8 (2), 143-161.

Suttipun, M., \& Stanton, P. (2012). Making or not making environmental disclosures in Thailand. International Journal of Business and Social Science, 3(9).

Syarifah, F. (12 Mei 2016). Tingkat polusi udara di Asia Tenggara meningkat 5 persen. Diakses dari https:// www.liputan6.com.

Ulhøi, J., \& Madsen, H. (2013). New patterns in corporate sustainable development? Procedia-Social and Behavioral Sciences, 99, 46-56.

Untari, L. (2010). Effect on company characteristics corporate social responsibility disclosures in corporate annual report of consumption listed in Indonesia stock exchange (Skripsi). Universitas Gunadarma.

Walhi. (25 Juli 2017). Ancaman kerusakan lingkungan hidup tambang pasir laut: Kasus Kab. Takalar, Sulwaesi Selatan. https://www.walhi.or.id.

Wuttichindanon, S. (2017). Corporate social responsibility disclosure choices of report and its determinants: Empirical evidence from firms listed on the Stock Exchange of Thailand. Kasetsart Journal of Social Sciences, 38(2), 156-162.

Yuliana, R., Purnomosidhi, B., \& Sukoharsono, E.G. (2008). Pengaruh karakteristik perusahaan terhadap pengungkapan corporate social responsibility (CSR) dan dampaknya terhadap reaksi investor. Jurnal Akuntansi dan Keuangan Indonesia, 5 (2), 245-276.

Yusoff, H., \& Lehman, G. (2006). Environmental engagements through the lens of disclosure practices: A Malaysian story. Asian Review of Accounting, 14(1/2), 122-148.

Zhongfu, Jianhui, Y.J., \& Pinglin, H. (2011). The study on the correlation between environmental information disclosure and economic performance with empirical data from the manufacturing industries at shanghai stock exchange in China. Energy Procedia, 5, 1218-1224.

Zuhroh, D., \& Sukmawati, I.P.P.H. (2003). Analisis pengaruh luas pengungkapan sosial dalam laporan tahunan perusahaan terhadap reaksi investor. Paper dipresentasikan pada acara Simposium Nasional Akuntansi VI, Surabaya. 